\title{
Etodolac, a selective cyclooxygenase- 2 inhibitor, induces apoptosis by activating caspases in human malignant rhabdoid tumor cells (FRTK-1)
}

\author{
MICHIYUKI HAKOZAKI ${ }^{1,2}$, HIROSHI HOJO ${ }^{1}$, SHINICHI KIKUCHI $^{2}$ and MASAFUMI ABE ${ }^{1}$ \\ ${ }^{1}$ First Department of Pathology and ${ }^{2}$ Department of Orthopaedic Surgery, Fukushima Medical \\ University School of Medicine, 1 Hikarigaoka, Fukushima-shi, Fukushima 960-1295, Japan
}

Received August 28, 2006; Accepted October 6, 2006

\begin{abstract}
Malignant rhabdoid tumor (MRT) is a rare and highly aggressive tumor presenting in the kidney and soft tissue in childhood. However, effective treatment for MRT has not been established. We investigated the antitumor effect of etodolac, a selective cyclooxygenase- 2 inhibitor, on MRT cells in vitro using the MRT cell line FRTK-1. Etodolac induced apoptosis of FRTK-1 cells through activation of caspase-8, -9 and -3. Moreover, several caspase inhibitors completely or partially inhibited etodolac-induced apoptosis. Our data indicated that etodolac had an antitumor effect on MRT cells and holds promise as a novel therapeutic strategy for MRT.
\end{abstract}

\section{Introduction}

Malignant rhabdoid tumor (MRT) is a very rare renal and soft tissue tumor that occurs in childhood, especially in infancy. Frequently MRT is highly aggressive, resistant to multi-agent chemotherapy, and fatal in metastasis (1). However, effective treatment for MRT has not been established, and more effective antitumor therapy for MRT must be developed in order to improve its aggressive biological behavior.

Cyclooxygenase (COX), also known as prostaglandin $\mathrm{H} 2$ synthase or prostaglandin endoperoxide synthase, is a key enzyme in the conversion of arachidonic acid to prostanoids (2). COX-2 is one of two COX types, the other being COX-1. COX-2 is undetectable in most normal tissues, but can be induced in various cell types by pro-inflammatory agents, growth factors and carcinogens (3). Overexpression of COX-2 in various malignancies, including carcinomas, lymphomas and some sarcomas, has been reported (4-11). COX-2 activation promotes tumor growth through production of prostaglandin E2, which blocks apoptosis or activates vascular endothelial

Correspondence to: Dr Michiyuki Hakozaki, First Department of Pathology, Fukushima Medical University School of Medicine, 1 Hikarigaoka, Fukushima-shi, Fukushima 960-1295, Japan

E-mail: paco@fmu.ac.jp

Key words: cyclooxygenase-2 inhibitor, etodolac, malignant rhabdoid tumor, FRTK-1 cell line, apoptosis, caspase growth factor and angiogenesis (12). There have been several studies on the induction of apoptosis in various carcinoma cells by selective COX-2 inhibitors and on the antitumor effects of some selective COX-2 inhibitors for soft tissue sarcoma cells (rhabdomyosarcoma and malignant fibrous histiocytoma) $(13,14)$. However, drug-induced apoptosis such as that in carcinoma cells has not been reported in soft tissue sarcomas. Thus, the pathways of selective COX-2 inhibitor-induced apoptosis also have not been recognized in soft tissue sarcomas. The present study revealed that etodolac, a selective COX-2 inhibitor, induced apoptosis of FRTK-1, an MRT cell line, through caspase activation.

\section{Materials and methods}

Reagent. Etodolac, a selective COX-2 inhibitor, was provided by Nippon Shinyaku Co. (Kyoto, Japan). Stock solution of etodolac was prepared in $99.5 \%$ ethanol and stored at $-80^{\circ} \mathrm{C}$. Caspase inhibitors (Z-VAD-FMK, broad caspase inhibitor; Ac-IETD-CHO, caspase-8 inhibitor; Ac-LEHD-CHO, caspase-9 inhibitor; Ac-DMQD-CHO, caspase-3 inhibitor) were obtained from Peptide Institute, Inc. (Osaka, Japan) and were dissolved in dimethyl sulfoxide (DMSO) as stock solutions.

Cell line. The FRTK-1 cell line was established in our laboratory from a surgical specimen of renal MRT in an 18month-old boy. The FRTK-1 cells showed overexpression of COX-2, as demonstrated by immunohistochemistry, Western blotting and reverse transcription-polymerase chain reaction analysis (15). FRTK-1 cells were grown in RPMI-1640 medium (Sigma R8758, St. Louis, MO, USA) supplemented with $15 \%$ heat-inactivated fetal calf serum (FCS) (JRH Biosciences, Lenexa, KS, USA), 50 units $/ \mathrm{ml}$ penicillin $\mathrm{G}$ and $50 \mu \mathrm{g} / \mathrm{ml}$ streptomycin. The cells were inoculated into $25-\mathrm{cm}^{2}$ tissue culture flasks (Iwaki Glass, Tokyo, Japan) and incubated at $37^{\circ} \mathrm{C}$ in a humidified atmosphere with $5 \% \mathrm{CO}_{2}$.

Measurement of etodolac-induced cell death in vitro. Cell viability was assessed using a cell proliferation reagent, WST-1 (Roche Diagnostics, Mannheim, Germany) (16). FRTK-1 cells were seeded in 96-well plates (BD Falcon 353072, BD Biosciences, Franklin Lakes, NJ, USA) at a dose of $1.0 \times 10^{4}$ 


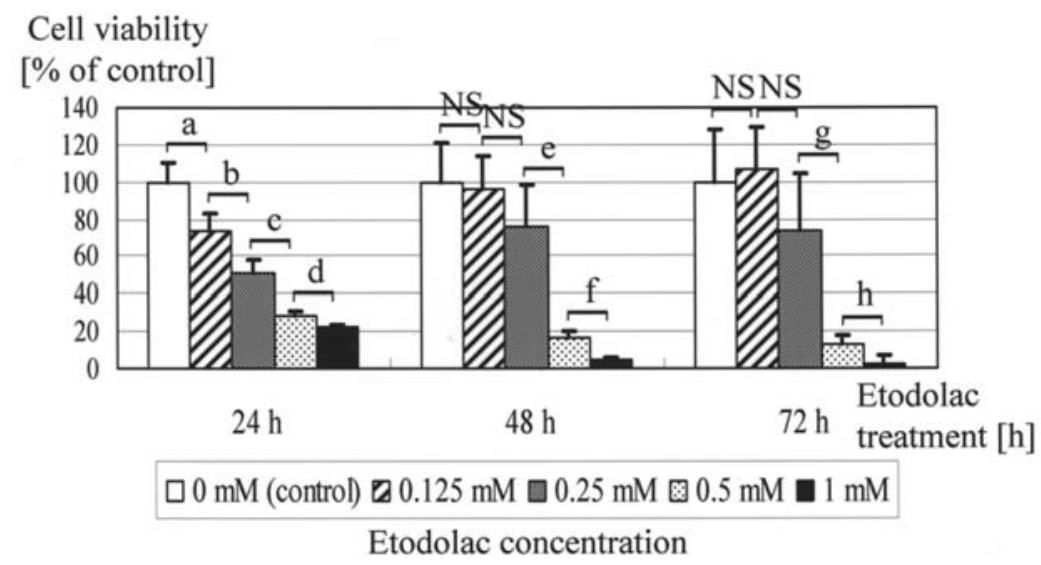

Figure 1. Effect of etodolac treatment on FRTK-1 cells. Etodolac significantly reduces cell viability in a dose-dependent manner ( $\mathrm{n}=5$ ). $\mathrm{p}$-values were calculated based on Student's t-test (a, p=0.0062; b, p=0.0067; c, p=0.0004; d, p=0.0007; e, p=0.0009; f, p=0.0001; g, p=0.0050; h, p=0.0063; NS, not significant).

cells/well and incubated for $24 \mathrm{~h}$ at $37^{\circ} \mathrm{C}$ in $100 \mu 1$ of phenolred-free RPMI-1640 medium (Sigma R7509) supplemented with $10 \%$ FCS, 50 units $/ \mathrm{ml}$ penicillin $\mathrm{G}, 50 \mu \mathrm{g} / \mathrm{ml}$ streptomycin and $200 \mathrm{mM}$ L-glutamine. FRTK-1 cells were treated by adding etodolac, and then dissolved and diluted to the desired concentration by $1 \mu \mathrm{l}$ of $99.5 \%$ ethanol with $49 \mu \mathrm{l}$ of culture medium (final concentration of ethanol: $\leq 0.67 \%$ ), at final concentrations of 0 (control), $0.125,0.25,0.5$ and $1 \mathrm{mM}$. At 24, 48 and $72 \mathrm{~h}$ after etodolac treatment, $15 \mu \mathrm{l}$ of WST-1 reagent was added to each well and the plates were incubated for $2 \mathrm{~h}$ at $37^{\circ} \mathrm{C}$. The plates were then shaken for $1 \mathrm{~min}$ at room temperature, and the absorbance of 450-655 nm was measured using a multi-well ELISA reader (Microplate Reader, Model 550, Bio-Rad Laboratories, Hercules, CA, USA).

Morphological analysis and DNA fragmentation analysis of dead cells. FRTK-1 cells were seeded in 6-well plates (BD

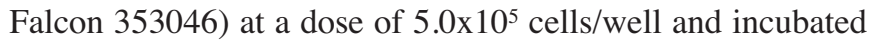
for $24 \mathrm{~h}$ at $37^{\circ} \mathrm{C}$ in $5 \mathrm{ml}$ of culture medium. FRTK-1 cells were treated by adding etodolac, dissolved and diluted to the desired concentration by $50 \mu 1$ of $99.5 \%$ ethanol (final concentration of ethanol: $\leq 0.99 \%$ ), at a final concentration of 0 (control) or $1 \mathrm{mM}$. At 24, 48 and $72 \mathrm{~h}$ after the etodolac treatment, cells were removed using a rubber policeman. For morphological analysis of dead cells, $50 \mu 1$ of the cell suspension was cytospun on silan-coated slides, which were stained by MayGiemsa staining and observed. Suspended cells were washed in ice-cold phosphate-buffered saline (PBS) twice and pelleted by centrifugation. To detect cell death, whether apoptotic or not, a DNA sample was extracted from each cell pellet using the Enhanced Apoptotic DNA ladder detection kit (BioVision, Mountain View, CA, USA) according to the manufacturer's protocol. Extracted DNA samples were electrophoresed through $1.8 \%$ agarose gels and stained with ethidium bromide.

Measurement of caspase-8, -9 and -3 activity. FRTK-1 cells were seeded in 6-well plates at a dose of $5.0 \times 10^{5}$ cells/well and incubated for $24 \mathrm{~h}$ at $37^{\circ} \mathrm{C}$ in $5 \mathrm{ml}$ of culture medium. FRTK-1 cells were treated by adding 0 (control) or $1 \mathrm{mM}$ etodolac, dissolved and diluted to the desired concentration by $50 \mu \mathrm{l}$ of $99.5 \%$ ethanol (final concentration of ethanol: $\leq 0.99 \%$ ). At 24 and $48 \mathrm{~h}$ after etodolac treatment, cells were removed with a rubber policeman. Suspended cells were washed in ice-cold PBS twice and pelleted by centrifugation. To detect the activity of caspase- $8,-9$ or -3 , samples were extracted from cell pellets and measured by the APOPCYTO Caspase-8, -9 or -3 colorimetric assay kit (MBL, Nagoya, Japan), according to the manufacturer's protocol. The 96-well plates were then shaken for $1 \mathrm{~min}$ at room temperature, and absorbance at $405 \mathrm{~nm}$ was measured using a multi-well ELISA reader. The activities of the caspases were corrected by protein concentrations.

Blockage of apoptosis by various caspase inhibitors. Cell viability was assessed by the WST-1 method. FRTK-1 cells were seeded in 96-well plates at a dose of $1.0 \times 10^{4}$ cells/well and incubated for $24 \mathrm{~h}$ at $37^{\circ} \mathrm{C}$ in $100 \mu \mathrm{l}$ of phenol-red-free medium. After $2 \mathrm{~h}$ of preincubation with 0 (control) or $100 \mu \mathrm{M}$ caspase inhibitors (Z-VAD-FMK, Ac-IETD-CHO, Ac-LEHD$\mathrm{CHO}$ or Ac-DMQD-CHO), dissolved and diluted to the desired concentration by $0.75 \mu \mathrm{l}$ of DMSO with $39.25 \mu \mathrm{l}$ of culture medium (final concentration of DMSO: $\leq 0.5 \%$ ), FRTK- 1 cells were treated by adding etodolac, dissolved and diluted to the desired concentration by $1.5 \mu \mathrm{l}$ of $99.5 \%$ ethanol with $8.5 \mu \mathrm{l}$ of culture medium (final concentration of ethanol: $\leq 1 \%$ ), at a final concentration of 0 (control) or $1 \mathrm{mM}$. At 24 and $48 \mathrm{~h}$ after etodolac treatment, $15 \mu \mathrm{l}$ of the WST- 1 reagent was added to each well and the plates were incubated for $2 \mathrm{~h}$ at $37^{\circ} \mathrm{C}$. The plates were then shaken for $1 \mathrm{~min}$ at room temperature, and the absorbance of 450-655 nm was measured using a multiwell ELISA reader.

Data analysis. Data were summarized as means \pm SD. Statistical analysis was performed using the unpaired Student's t-test. $\mathrm{p}<0.05$ was considered statistically significant. All data were representative from two independent experiments.

\section{Results}

Etodolac-induced cell death in vitro. FRTK-1 cells inhibited growth in a dose-dependent manner (Fig. 1). With 0.125 or $0.25 \mathrm{mM}$ of etodolac treatment, the viability of FRTK-1 cells 


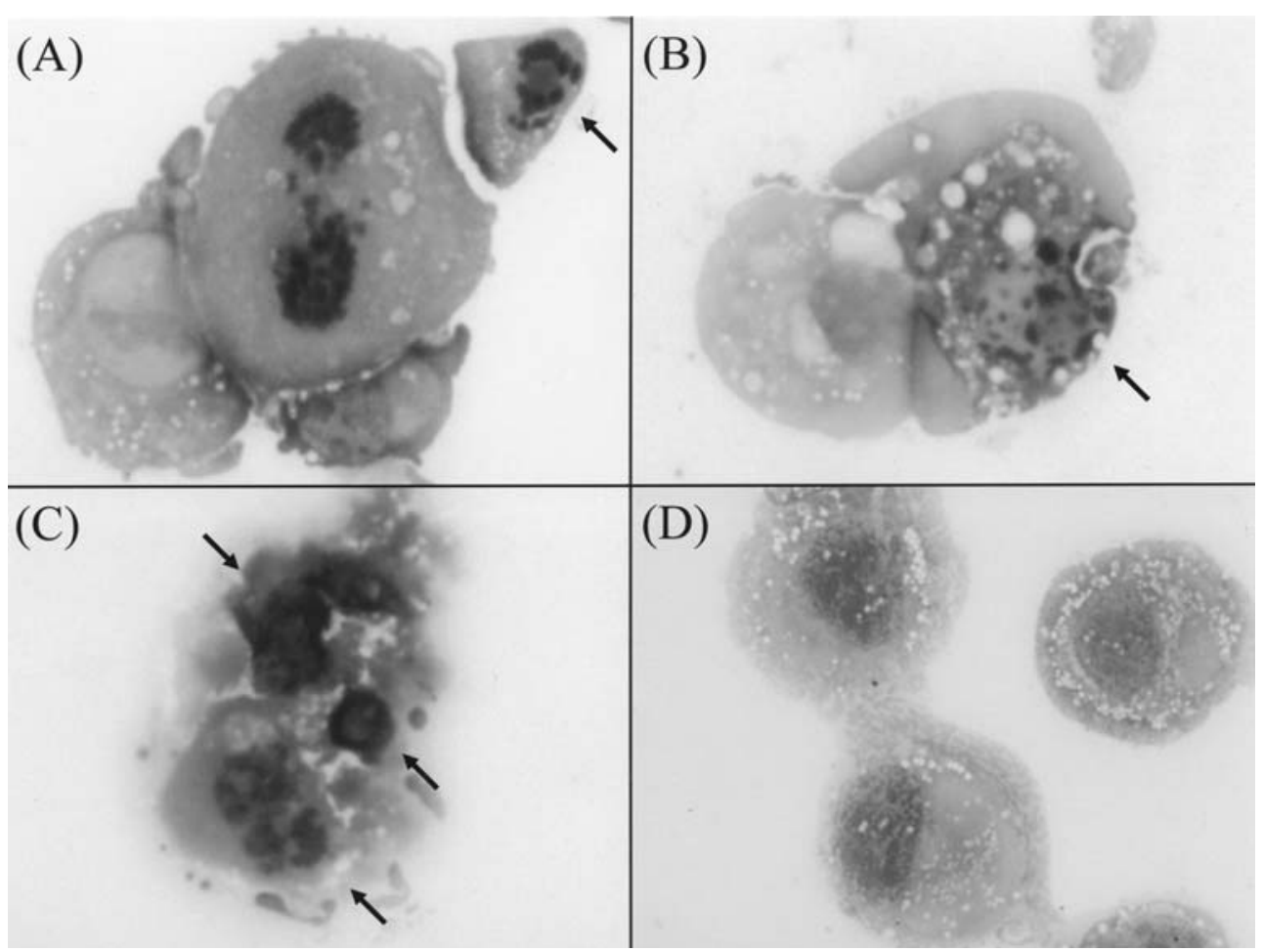

Figure 2. Morphology of FRTK-1 cells after etodolac treatment for $24 \mathrm{~h}$ (A), $48 \mathrm{~h}$ (B) and $72 \mathrm{~h}$ (C). Nuclear fragmentations are observed (arrows), in contrast to viable cells without etodolac treatment (72 h) (D). (May-Giemsa staining, $\mathrm{x} 400$ )

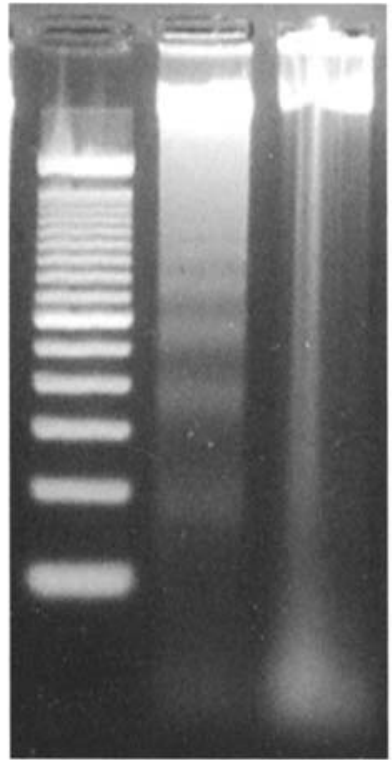

Marker Etodolac Control

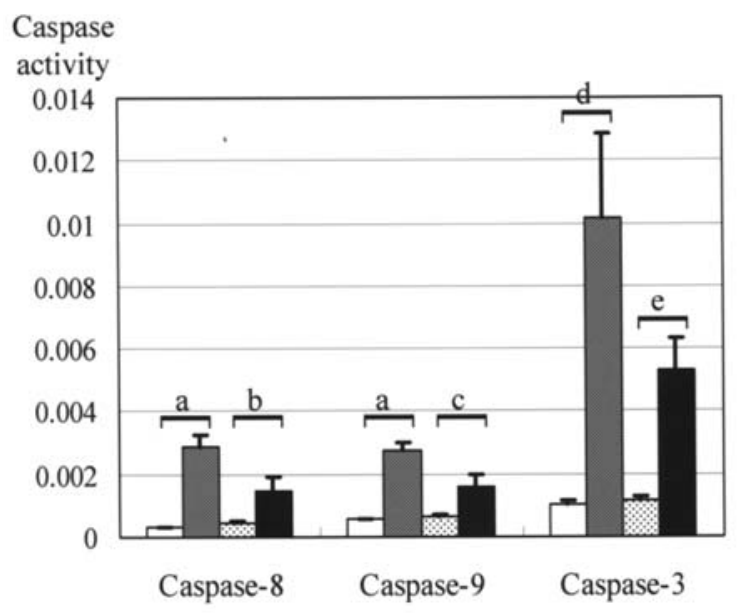

$\square 24 \mathrm{~h}$ Control $\square 24 \mathrm{~h} 1 \mathrm{mM}$ Etodolac : 48h Control $48 \mathrm{~h} 1 \mathrm{mM}$ Etodolac

Figure 4. Activities of caspase- $8,-9$ and -3 with etodolac treatment $(24$ and $48 \mathrm{~h})(\mathrm{n}=3)$. $\mathrm{p}$-values were calculated based on Student's t-test (a, $\mathrm{p}=0.0006$; $\mathrm{b}, \mathrm{p}=0.0424 ; \mathrm{c}, \mathrm{p}=0.0173 ; \mathrm{d}, \mathrm{p}=0.0091 ; \mathrm{e}, \mathrm{p}=0.0047)$.

Figure 3. Evaluation of apoptosis using agarose gel electrophoresis. Lane 1, Marker, 100-bp DNA ladder; lane 2, Etodolac treatment (72 h); lane 3, Control (without etodolac treatment, $72 \mathrm{~h}$ ).

was inhibited at $24 \mathrm{~h}$, but recovered at 48 and $72 \mathrm{~h}$. There was no statistically significant difference in cell viability between the etodolac treatment group and the control group at 48 and $72 \mathrm{~h}$; however, with 0.5 or $1 \mathrm{mM}$ of etodolac, cell viability was inhibited at $24 \mathrm{~h}$ and not recovered at 48 or $72 \mathrm{~h}$.
Morphological analysis and DNA fragmentation analysis of dead cells. May-Giemsa staining showed nuclear fragmentation in the dead cells after $24 \mathrm{~h}$ of etodolac treatment (Fig. 2). Agarose gel electrophoresis of extracted DNA samples from the dead cells revealed a DNA ladder, indicating apoptosis (Fig. 3).

Activation of caspase-8, -9 and -3 with etodolac treatment. FRTK-1 cells treated with etodolac showed activation of 


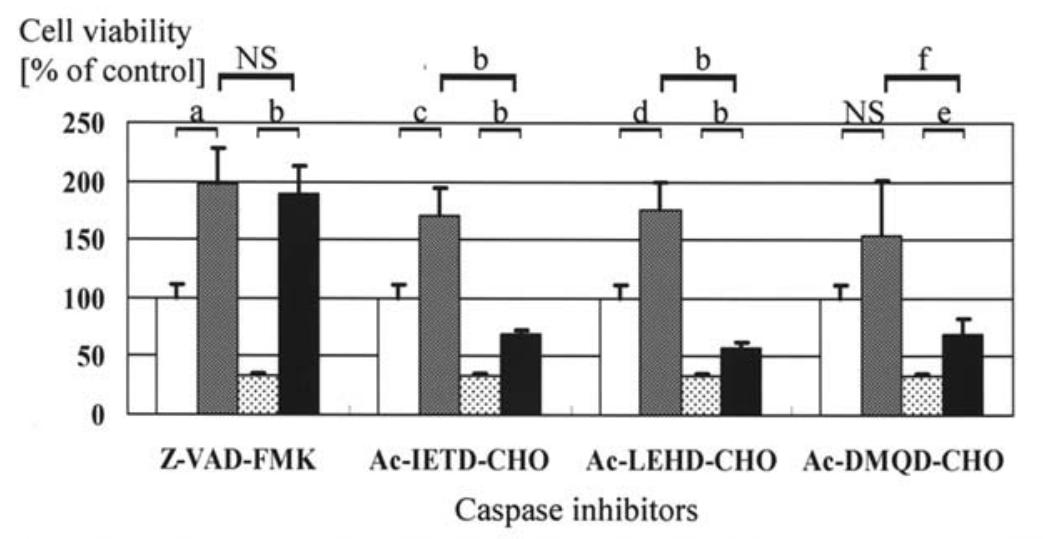

$\square$ Control $\square$ Caspase inhibitor $⿴ 1 \mathrm{mM}$ Etodolac $\square 1 \mathrm{mM}$ Etodolac + Caspase inhibitor

Figure 5. Effects of several caspase inhibitors on etodolac treatment $(48 \mathrm{~h})(\mathrm{n}=5)$. $\mathrm{p}$-values were calculated based on Student's t-test. $(\mathrm{a}, \mathrm{p}=0.0003$; $\mathrm{b}$, $\mathrm{p}<0.0001$; $\mathrm{c}, \mathrm{p}=0.0005 ; \mathrm{d}, \mathrm{p}=0.0003 ; \mathrm{e}, \mathrm{p}=0.0004 ; \mathrm{f}, \mathrm{p}=0.0083 ; \mathrm{NS}$, not significant)

caspase- $8,-9$ and -3 at 24 or 48 h compared with the control group, which was not treated with etodolac (Fig. 4).

Inhibition of apoptosis by caspase inhibitors. Z-VAD-FMK, a broad caspase inhibitor, almost completely inhibited etodolacinduced apoptosis of FRTK-1 cells. Each of the caspase inhibitors, Ac-LEHD-CHO (a caspase- 8 inhibitor), AcIETD-CHO (a caspase-9 inhibitor) and Ac-DMQD-CHO (a caspase-3 inhibitor), incompletely inhibited etodolac-induced apoptosis (Fig. 5).

\section{Discussion}

The present study revealed that etodolac, a selective COX-2 inhibitor, induced death in FRTK-1 cells (MRT cell line), and this death was demonstrated to be apoptotic by the results of a morphological examination (apoptotic body) and agarose gel electrophoresis (DNA ladder).

The apoptotic event was shown to occur in FRTK-1 cells through the activation of caspase- $8,-9$ and -3 , as these caspases were activated in the FRTK-1 cells treated with etodolac. In addition, etodolac-induced apoptosis was completely inhibited by Z-VAD-FMK, a broad caspase inhibitor. However, each caspase inhibitor (caspase-8 inhibitor Ac-IETD-CHO, caspase-9 inhibitor Ac-LEHD-CHO, and caspase-3 inhibitor Ac-DMQD-CHO) showed incomplete inhibition of etodolac-induced apoptosis. These results suggest that the caspase cascade of etodolac-induced apoptosis of FRTK-1 cells involves various caspase pathways.

There have been several studies on the molecular mechanisms or factors involved in selective COX-2 inhibitorinduced apoptosis; down-regulation in bcl-2 protein expression (17), augmentation of TRAIL (tumor necrosis factor-related apoptosis-inducing ligand)-induced apoptosis (18), augmentation of Fas-mediated apoptosis (19), cytochrome c-dependent pathway (20), blocking of Akt activation (21), and increase in arachidonic acid and ceramide (22). In addition, apoptotic pathways in the selective COX-2 inhibitor-induced apoptosis of tumor cells depend on tumor cell types or selective COX-2 inhibitor types. However, the signaling pathways from the first signal initiated by etodolac to caspase activation have not been sufficiently elucidated. Therefore, it is necessary to investigate how caspase activation occurs.

Combined chemotherapy using selective COX-2 inhibitor and other antitumor drugs, such as carboplatin, is known to have synergistic effects in some tumors (23). There is crosstalk between epidermal growth factor receptor (EGFR) and COX-2 $(24,25)$, and cooperative cell-growth in some carcinomas is shown to be inhibited by the combination treatment with an EGFR tyrosine kinase inhibitor, ZD1839, and a selective COX-2 inhibitor (26-29). In addition, the growth of MRT cells with EGFR expression demonstrates inhibition by a selective EGFR tyrosine kinase inhibitor, Gefitinib (ZD1839, Iressa), in vitro and in vivo (30). Therefore, the present results suggest that the combination of the EGFR tyrosine kinase inhibitor and a selective COX-2 inhibitor might be a promising effective therapy for MRT.

In conclusion, etodolac, a selective COX-2 inhibitor, induced apoptosis of FRTK-1 cells through the activation of caspase- $8,-9$ and -3 . Although the selective COX-2 inhibitorinduced apoptosis of osteosarcoma cells has already been reported (31), the present study is the first, to our knowledge, to cover the apoptosis of MRT cells induced by the selective COX-2 inhibitor. This inhibitor might be effective for other aggressive sarcomas.

\section{References}

1. Weeks DA, Beckwith JB, Mierau GW and Luckey DW: Rhabdoid tumor of kidney. A report of 111 cases from the National Wilms' Tumor Study Pathology Center. Am J Surg Pathol 13: 439-458, 1989.

2. Vane JR, Bakhle YS and Botting RM: Cyclooxygenases 1 and 2. Annu Rev Pharmacol Toxicol 38: 97-120, 1998.

3. Dubois RN, Abramson SB, Crofford L, Gupta RA, Simon LS, Van De Putte LB and Lipsky PE: Cyclooxygenase in biology and disease. FASEB J 12: 1063-1073, 1998.

4. Turini ME and DuBois RN: Cyclooxygenase-2: a therapeutic target. Annu Rev Med 53: 35-57, 2002.

5. Hazar B, Ergin M, Seyrek E, Erdogan S, Tuncer I and Hakverdi S: Cyclooxygenase-2 (Cox-2) expression in lymphomas. Leuk Lymphoma 45: 1395-1399, 2004.

6. Cetin M, Buyukberber S, Demir M, Sari I, Sari I, Deniz K, Eser B, Altuntas F, Camci C, Ozturk A, Turgut B, Vural O and Unal A: Overexpression of cyclooxygenase-2 in multiple myeloma: association with reduced survival. Am J Hematol 80: 169-173, 2005. 
7. Dickens DS, Kozielski R, Khan J, Forus A and Cripe TP: Cyclooxygenase-2 expression in pediatric sarcomas. Pediatr Dev Pathol 5: 356-364, 2002.

8. Sutton KM, Wright M, Fondren G, Towle CA and Mankin HJ: Cyclooxygenase-2 expression in chondrosarcoma. Oncology 66: 275-280, 2004.

9. Yamashita H, Osaki M, Ardyanto TD, Osaki M, Yoshida H and Ito $\mathrm{H}$ : Cyclooxygenase-2 in human malignant fibrous histiocytoma: correlations with intratumoral microvessel density, expression of vascular endothelial growth factor and thymidine phosphorylase. Int J Mol Med 14: 565-570, 2004.

10. Raspollini MR, Amunni G, Villanucci A, Paglierani M and Taddei GL: Cyclooxygenase-2 expression in uterine leiomyosarcomas. J Chemother 16: 577-581, 2004.

11. Lassus P, Ristimaki A, Huuhtanen R, Tukiainen E, Andersson LC, Asko-Seljavaara S, Miettinen M, Blomqvist C, Haglund C and Bohling T: Cyclooxygenase-2 expression in human soft-tissue sarcomas is related to epithelial differentiation. Anticancer Res 25: 2669-2674, 2005

12. Gately S and Li WW: Multiple roles of COX-2 in tumor angiogenesis: a target for antiangiogenic therapy. Semin Oncol 31: 2-11, 2004.

13. Dickens DS and Cripe TP: Effect of combined cyclooxygenase-2 and matrix metalloproteinase inhibition on human sarcoma xenografts. J Pediatr Hematol Oncol 25: 709-714, 2003.

14. Yamashita H, Osaki M, Honjo S, Yoshida H, Teshima R and Ito H: A selective cyclooxygenase-2 inhibitor, NS-398, inhibits cell growth by cell cycle arrest in a human malignant fibrous histiocytoma cell line. Anticancer Res 23: 4671-4676, 2003.

15. Hakozaki M, Hojo H, Sato M, Kaneko Y, Watanabe N, Kikuchi S and Abe M: Establishment and characterization of a new cell line, FRTK-1, derived from human malignant rhabdoid tumor of the kidney, with overexpression of epidermal growth factor receptor and cyclooxygenase-2. Oncol Rep 16: 265-271, 2006.

16. Bajorath J: Analysis of Fas-ligand interactions using a molecular model of the receptor-ligand interface. J Comput Aided Mol Des 13: 409-418, 1999.

17. Liu XH, Yao S, Kirschenbaum A and Levine AC: NS398, a selective cyclooxygenase-2 inhibitor, induces apoptosis and down-regulates bcl-2 expression in LNCaP cells. Cancer Res 58: 4245-4249, 1998.

18. Tang X, Sun YJ, Half E, Kuo MT and Sinicrope F: Cyclooxygenase- 2 overexpression inhibits death receptor 5 expression and confers resistance to tumor necrosis factor-related apoptosisinducing ligand-induced apoptosis in human colon cancer cells Cancer Res 62: 4903-4908, 2002.

19. Nzeako UC, Guicciardi ME, Yoon JH, Bronk SF and Gores GJ: COX-2 inhibits Fas-mediated apoptosis in cholangiocarcinoma cells. Hepatology 35: 552-559, 2002.

20. Li M, Wu X and Xu XC: Induction of apoptosis in colon cancer cells by cyclooxygenase-2 inhibitor NS398 through a cytochrome c-dependent pathway. Clin Cancer Res 7: 1010-1016, 2001.
21. Hsu AL, Ching TT, Wang DS, Song X, Rangnekar VM and Chen CS: The cyclooxygenase-2 inhibitor celecoxib induces apoptosis by blocking Akt activation in human prostate cancer cells independently of Bcl-2. J Biol Chem 275: 11397-11403, 2000.

22. Chan TA, Morin PJ, Vogelstein B and Kinzler KW: Mechanisms underlying nonsteroidal antiinflammatory drug-mediated apoptosis. Proc Natl Acad Sci USA 95: 681-686, 1998.

23. Mishima K, Nariai Y and Yoshimura Y: Etodolac, a selective cyclooxygenase-2 inhibitor, enhances carboplatin-induced apoptosis of human tongue carcinoma cells by down-regulation of FAP-1 expression. Oral Oncol 41: 77-81, 2005.

24. Dannenberg AJ, Lippman SM, Mann JR, Subbaramaiah K and DuBois RN: Cyclooxygenase-2 and epidermal growth factor receptor: pharmacologic targets for chemoprevention. J Clin Oncol 23: 254-266, 2005

25. Lippman SM, Gibson N, Subbaramaiah K and Dannenberg AJ: Combined targeting of the epidermal growth factor receptor and cyclooxygenase-2 pathways. Clin Cancer Res 11: 6097-6099, 2005.

26. Tortora G, Caputo R, Damiano V, Melisi D, Bianco R, Fontanini G, Veneziani BM, De Placido S, Bianco AR and Ciardiello F: Combination of a selective cyclooxygenase-2 inhibitor with epidermal growth factor receptor tyrosine kinase inhibitor ZD1839 and protein kinase A antisense causes cooperative antitumor and antiangiogenic effect. Clin Cancer Res 9: 1566-1572, 2003.

27. Chen Z, Zhang X, Li M, Wang Z, Wieand HS, Grandis JR and Shin DM: Simultaneously targeting epidermal growth factor receptor tyrosine kinase and cyclooxygenase-2, an efficient approach to inhibition of squamous cell carcinoma of the head and neck. Clin Cancer Res 10: 5930-5939, 2004.

28. Zhang X, Chen ZG, Choe MS, Lin Y, Sun SY, Wieand HS, Shin HJ, Chen A, Khuri FR and Shin DM: Tumor growth inhibition by simultaneously blocking epidermal growth factor receptor and cyclooxygenase-2 in a xenograft model. Clin Cancer Res 11: 6261-6269, 2005

29. Melisi D, Caputo R, Damiano V, Bianco R, Veneziani BM, Bianco AR, De Placido S, Ciardiello F and Tortora G: Zoledronic acid cooperates with a cyclooxygenase- 2 inhibitor and gefitinib in inhibiting breast and prostate cancer. Endocr Relat Cancer 12: 1051-1058, 2005.

30. Kuwahara Y, Hosoi H, Osone S, Kita M, Iehara T, Kuroda H and Sugimoto T: Antitumor activity of gefitinib in malignant rhabdoid tumor cells in vitro and in vivo. Clin Cancer Res 10: 5940-5948, 2004.

31. Moalic-Juge S, Liagre B, Duval R, Corbiere C, Bianchi A, Bordji K, Bosgiraud C and Beneytout JL: The anti-apoptotic property of NS-398 at high dose can be mediated in part through NF-kappaB activation, hsp70 induction and a decrease in caspase-3 activity in human osteosarcoma cells. Int J Oncol 20: $1255-1262,2002$. 